Janez Orešnik (University of Ljubljana), Andrej Snedec (University of Maribor), Karmen Teržan (University of Maribor), and Frančiška Trobevšek-Drobnak (University of Ljubljana)

\title{
INTRODUCTION TO THE SUBSEQUENT THREE PAPERS IN THE PRESENT VOLUME
}

The subsequent three papers in the present volume (viz. Snedec', Teržan's, and Trobevšek-Drobnak's) have arisen from the research in historical syntax conducted since 1986 by us in the Department for Germanic Languages and Literatures of the University of Ljubljana, Yugoslavia, under the advisorship of J. Orešnik.

\section{THE THEORETICAL BACKGROUND OF OUR WORK}

We postulate the reality of such pairs of syntactic constructions in which one member is a STRENGTHENED construction, and the other member a NONSTRENGTHENED construction. The two constructions of each such pair display the following traits:

1.1. Formally (ie in structure and sound body), a strengthened construction is more elaborate than the corresponding non-strengthened construction.

1.2. Semantically, a strengthened construction expresses a subset of the meanings (including grammatical meanings) of the corresponding non-strengthened construction. Sometimes (usually?) there is also a stylistic difference between the two (say in emphasis, emotional colouring, intensity, contrast).

1.3. From the speaker's point of view, a strengthened construction is less economical to produce than the corresponding non-strengthened construction.

1.4. From the hearer's point of view, a strengthened construction is easier to decode than the corresponding non-strengthened construction.

We also postulate the reality of such pairs of syntactic constructions in which one member is a WEAKENED construction, and the other member a NONWEAKENED construction. The two constructions display the following traits:

1.5. Formally, a weakened construction is less elaborate than the corresponding non-weakened construction.

1.6. Semantically, a weakened construction expresses more meanings (grammatical meanings included) than the corresponding non-weakened construction. Usually the meanings of the weakened construction are expressed more opaquely than the meanings of the corresponding non-weakened construction. 
1.7. From the speaker's point of view, a weakened construction is more economical to produce than the corresponding non-weakened construction.

1.8. From the hearer's point of view, a weakened construction is more difficult to decode than the corresponding non-weakened construction.

Illustration. The often quoted instance of a syntactic syncretism, old men and women (Coseriu 1988: 227) is a weakened construction with respect to old men and old women, whenever the two constructions mean the same. In the (weakened) old men and women the decoding of the common meaning is likely to be more difficult than in the (non-weakened) old men and old women; the difficulty stems in part from the circumstance that the noun phrase old men and women also has a meaning associated with the structure in which old modifies men only.

The point of view can be reversed, and then the noun phrase old men and old women can be interpreted as a strengthened variant of the non-strengthened old men and women.

Which point of view is assumed in a given case, depends - in historical studies - on which construction is the older one, and - in descriptive studies - on which construction is felt as the normal one.

Our characterisation 1 of strengthened and weakened constructions should not be taken to imply, (a) that the traits enumerated there are the only relevant traits of those constructions, and (b) that strengthened constructions are always difficult for the speaker to use, and, conversely, that weakened constructions are invariably easy to use. That (b) does not hold can be seen from the circumstance that many periphrastic (thus strengthened) constructions have more regular structure than their nonstrengthened counterparts, which circumstance makes those periphrastic constructions relatively easy to use. Eg English did not go was more regular (contained, and still contains, a more widely used - hence more natural - irregularity) than went not (at the time that the two were still syntactic variants of each other).

It is our basic assumption that weakened construction assert themselves under relatively simple grammatical conditions to begin with (and may subsequently spread elsewhere); and that strengthened constructions assert themselves under relatively complex grammatical conditions to begin with (and may subsequently spread elsewhere).

'To begin with' of the preceding paragraph means: after the nascent state, and before the grammaticalisation, of the construction in question. - For more comment, cf 5.3-4 below.

As to the source of our basic assumption, we can mention that we have been influenced (a) by those linguists who advocate the dichotomy of language changes into those serving economy and into those designed to serve the clarity of the message (cf Havers 1931: 171 on 'Bequemlichkeitstrieb' and on 'Deutlichkeitstrieb'; a convenient summary of Havers and later work in Braun 1987: $94 \mathrm{ff}$ ), and (b) by the socalled Natural Phonology and Natural Morphology.

Natural Morphology teaches, among other things, the so-called CONSTRUCTIONAL ICONISM: the more marked a form is, the more complex ('markful') is its encoding. (Cf Mayerthaler 1980: $23 \mathrm{ff}$ and passim.) 
From these sources, and from our own study of the published descriptions of sundry syntactic developments, we reached the above formulation of our basic assumption.

To confirm or disconfirm this assumption, we have investigated several syntactic constructions. The investigations are reported in the three subsequent papers published in the present volume. The present paper is an indispensible introduction to them, in the sense that everything that is common to the three investigations has been moved hither, to avoid unnecessary repetition.

2. THE STRUCTURE OF THE ARGUMENTATION associated with our investigations is as follows.

2.1. A working hypothesis (see section 3 below) was formulated.

2.2. A number of falsifiable predictions were stated on the basis of the working hypothesis.

2.3. Those predictions wer tested.

2.4. In so far as the predictions obtained, the working hypothesis was considered confirmed/verified by the 'facts'.

\section{THE WORKING HYPOTHESIS}

Our working hypothesis rests (a) on the assumption that the constructions studied are strengthened constructions, (b) on the assumption about what is simple and what complex in language, (c) on the assumption about the grammatical conditions under which strengthened constructions assert themselves during the 'early' stage of their development.

The constructions that we have investigated are all strengthened constructions. Under our basic assumption, they are used prevailingly under more complex grammatical conditions than the corresponding non-strengthened constructions.

The question as to what is simple/complex in languages of the world has been studied especially by the Prague School (an early case study is Jakobson 1932). The Praguians operate with 'marked' and 'unmarked' values of phonological, grammatical, and other parameters. This terminology will also be employed in the present paper, where, in matters of detail, Natural Morphology has mostly been followed, more precisely Mayerthaler 1980; our markedness values are Mayerthaler's 'semvalues', to a lesser extent his 'sym-values' (which, we believe, become also 'semvalues' via the constructional iconism). Here follow some of the assumptions about markedness values, chosen for their relevance to the matter in hand:

3.1. An independent clause is 'less marked' than a dependent clause.

3.2. The affirmative propositional modality is 'less marked' than the nonaffirmative propositional modalities. 
3.3. The present tense is 'less marked' than the non-present tenses.

3.4. The indicative mood is 'less marked' than the non-indicative moods.

3.5. The singular is 'less marked' than the non-singular.

3.6. The active voice is 'less marked' than the non-active voices.

3.7. Verb + direct object (in the accusative) is 'less marked' than verb + prepositional object or verb + object clause.

Concerning the assumptions stated sub 3.1-7, we estimate that consensus can be assumed of those linguists who have worked with the markedness theory. On the other hand, we did not follow Mayerthaler 1980 in the markedness values of the verbal persons, but have kept to the older view (Watkins 1969: 49 with references to relevant argumentation), again assuming the concurring opinion of most linguists sympathetic to the markedness theory:

3.8. The third person is 'less marked' than the non-third persons.

\section{THE GRAMMATICAL ANALYSIS AND THE STATISTICAL WORK}

In each investigation, two samples have been formed, a basic sample and a control sample. The basic sample contains all clauses of the corpus containing the instances of the investigated strengthened construction(s), whereas the control sample contains a representative number of clauses of the corpus containing either the corresponding non-strengthened construction(s) or all constructions except the investigated strengthened constructions.

To confirm or disconfirm our predictions, certain grammatical parameters were chosen in each investigation for analysis. The choice of the grammatical parameters was suggested (a) by the properties of the basic sample and (b) by the state of the art of the markedness theory (not all possible grammatical parameters have been treated by the markedness theory, or consensus has so far not been reached about the allotment of markedness values to certain grammatical parameters).

After the grammatical analysis, the statistical work was performed. For statistical purposes, the content of the crucial statement, 'strengthened constructions assert themselves under relatively complex grammatical conditions', was interpreted in the following way. Given (a) the probability rate of the 'more marked' value of a given grammatical parameter in a given strengthened construction, and given (b) the probability rate of the 'more marked' value of the same grammatical parameter in the corresponding non-strengthened construction - or generally outside the strengthened construction -, then (c) the former probability rate is higher than the latter probability rate, and (d) the difference between the two probability rates is statistically significant.

The statistical procedure followed is described briefly in Trobevšek-Drobnak (in the present volume). 


\section{COMMENTARY}

Let us measure the success of the three investigations reported in the present volume in terms of confirmed and disconfirmed predictions. This can be done with the help of the statistical data adduced in the various tables of those papers. Arbitrarily, let us allot the value +1 to any significant result that confirms one of the predictions, the value $7^{1}$ to any significant result that disconfirms one of the predictions, and the value $+1 / 2$ to any non-significant result that confirms one of the predictions, and the value $-1 / 2$ to any non-significant result that disconfirms one of the predictions; then the overall success of Snedec' nad Teržan's investigations is around $75 \%$, that of Trobevšek-Drobnak's somewhat less.

Unfortunately, all too many real 'excuses' can be adduced for non-obtaining predictions. I list some of the 'excuses' here, in order to show their range and depth.

5.1. Our predictions are valied first of all for 'ideal' texts, where 'ideal' means: the quantity of instances in the text of any parameter value conforms with the assumptions of the markedness theory about the relative frequency of the competing values of the same grammatical parameter, ie each 'less marked' parameter value occurs more frequently than each corresponding 'more marked' parameter value. By way of example, consider the grammatical parameter NUMBER; since its parameter value SINGULAR is 'less marked' than the opposed parameter value PLURAL (according to the markedness theory), an 'ideal' text contains fewer instances of PLURAL than of SINGULAR. (How much fewer instances, is a further question, which we are not able to answer; we only stipulate that, in texts of suitable length, the difference in the frequency of the two parameter values is statistically significant.)

Whether 'ideal' texts, in our sense of the term, do have reality, is an open empirical question. At any rate, we believe that unprepared spoken texts of a conversational nature come nearest to the 'ideal'.

5.2. Our statistics may not be fully reliable, for reasons having to do with the philological aspect of the texts investigated. It has been pointed out time and again in the linguistic and philological literature that the lack in written texts of overt markers of certain grammatical parameters (eg the lack of information on the sentence intonation), not to dwell on the lack of punctuation in old texts, may hamper the correct computation of statistical figures in written texts.

5.3. Our predictions are valid for the 'early' stage in the development of a syntactic construction, in which stage those constructions have already emerged from their nascent state.

A syntactic construction may be weakened during its nascent state, and may acquire the attributes of a strengthened construction only later on.

By way of exemplification, consider the origin of the do-support in English (understood as in Quirk et al. 1985: 80). If the plausible view is correct that the model for the $d o$-support has been provided by the English causative construction using the causative verb $d o$ (Ellegård 1953), then the $d o$-support was originally a weakened construction, and the causative construction with the causative do the corresponding 
non-weakened construction. Eg he did build a church 'he built a church' was weakened with respect to he did build a church 'he had a church built': the causative construction contains two different subjects (namely one of did and one of build), whereas the construction with $d o$-support contains just one subject (namely of both did and build); the causative do has more lexical meaning than the (almost empty) $d o$ of the do-support. Accordingly, we assume in the spirit of our predictions that the hypothetical weakened construction asserted itself under simple grammatical conditions to begin with, eg in the third person singular present indicative (active) of the auxiliary verb $d o$. Only the next stage in the hypothetical development (ie the next syntactic change) was that constructions such as he did build a church (do-support), having joined the paradigm of the tenses, became the syntactic variants of constructions containing simple verbs such as he built; from the standpoint of the simple tenses they then began to be felt as strengthened, and consequently began to favour complex grammatical conditions.

The danger here is that a given construction may not have emerged from its nascent state at the time of the writing of the text investigated or of its manuscript(s). Whenever that is the case, those non-obtaining predictions applicable to the 'early' stage of the construction cannot be held against our working hypothesis.

5.4. Our predictions are valid for the 'early' stage in the development of syntactic constructions, in which stage those constructions have not yet been grammaticalised, ie are still just syntactic variants of some other expressions. (We do not know in how far our predictions are also valid for partly grammaticalised constructions.)

5.5. A given text may not be suitable for statistical investigations, eg because it is extremely heterogeneous (so the statistical generalisations extracted from it are spurious), or because it is too short (and so the statistical significance of the results cannot be attained).

5.6. A given prediction may not obtain because some change in another grammatical parameter (possibly in one not included in the investigation), say the change in a non-syntactic parameter, may have intervened and 'spoiled' the picture. A case in point is the 'early' development of English constructions displaying the do-support. For a time, the constructions containing the auxiliary $d o$ were just syntactic variants of the corresponding constructions without the auxiliary do (ie as long as the constructions containing do-support were not yet grammaticalised), eg as long as he did go was a syntactic variant of (more precisely, was a strengthened) he went; at that time, we predict, the use of the do-support was relatively more frequent in the plural than in the singular. Yet Stein 1985 has shown that the opposite in fact obtained, as far as the second person was concerned: the use of the type thou didst go (second person singular) war relatively more frequent than the use of the type you did go (second person plural). The reason for this situation was, according to Stein, that the second person singular person marker -st had caused such difficulties in the pronunciation, in conjunction with the stem final consonant(s) (whenever the stem ended in a consonant (cluster)), that recourse had to be taken, by way of avoidance strategy, 
to a relatively frequent use of the auxiliary $d o$. This move on the one hand restricted the use of the person marker -st (first of all to the auxiliary (to its forms dost, didst), plus to a few other much-used verbs), and on the other hand spoiled the expected frequency of the plural.

The situation in the first and third persons, where do-support ought to be relatively more frequent in the plural than in the singular, according to our working hypothesis, cannot be verified with the aid of Stein's statistics; Stein adduces only the totals for all the persons lacking overt person markers together.

5.7. Although we have limited the grammatical parameters investigated to some of those whose markedness values we assume to be uncontroversial (as mentioned above in section 3.2), there remains the possibility that some of the markedness values operated with here are actually wrong, and our predictions consequently not fully confirmed for this reason.

\section{CONCLUDING REMARK}

It is to be pointed out that the existing theories of syntax do not predict the reality of situations such as described in our basic assumption. If we are right, the existing theories of syntax are in need of revision.

\section{BIBLIOGRAPHY}

Braun, Peter. Tendenzen in der deutschen Gegenwartssprache. Sprachvarietäten. Second edition. Stuttgart: Kohlhammer. 1987.

Coseriu, Eugenio. Einführung in die Allgemeine Sprachwissenschaft. Tübingen: Francke. 1988.

Ellegård, Alvar. The Auxiliary Do. The Establishment and Regulation of its Use in English. Stockholm: Almqvist \& Wiksell. 1953.

Havers, Wilhelm. Handbuch der erklärenden Syntax. Ein Versuch zur Erforschung der Bedingungen und Triebkräfte in Syntax und Stilistik. Heidelberg: Winter. 1931.

Jakobson, Roman. "Zur Struktur des russischen Verbums." In: Charisteria G. Mathesio. Prague: Cercle Linguistique de Prague, 1932, 74-84.

Mayerthaler, Willi. Morphologische Natürlichkeit. Wiesbaden: Athenaion. 1980. Quirk, Randolph, Sidney Greenbaum, Geoffrey Leech, and Jan Startvik. A Comprehensive Grammar of the English Language. London and New York: Longman. 1985.

Stein, Dieter. Natürlicher syntaktischer Sprachwandel. München: Tuduv. 1985. Watkins, Calvert. Geschichte der indogermanischen Verbalflexion (= Indogermanische Grammatik III: Formenlehre, 1). Heidelberg: Winter. 1969. 


\section{Povzetek}

\section{UVOD K NASLEDNJIM TREM CLLANKOM V PRIČUJOČI ŠTEVILKI ČASOPISA}

V tem Uvodu so združene tiste misli naslednjih treh člankov (v pričujoči številki), ki so tem besedilom skupne. Gre za teoretični okvir posameznih raziskav, za način utemljevanja, za delovno domnevo, za postopek pri slovnični analizi in statistični obdelavi ter za opazke o uspešnosti delovne domneve.

Teoretični okvir. Postuliramo take pare skladenjskih zgradb, $v$ katerih je ena zgradba OKREPLJENA, druga NEOKREPLJENA. V primerjavi z neokrepljeno zgradbo je okrepljena oblikovno bolj izdelana, pomensko ožja, manj gospodarna, laže razberljiva. Dalje postuliramo take pare skladenjskih zgradb, v katerih je ena zgradba OŠIBLJENA, druga NEOŠIBL JENA. V pimerjavi z neošibljeno zgradbo je ošibljena oblikovno manj izdelana, pomensko šiřa, bolj gospodarna, teže razberljiva.

Osnovna domneva je, da se uveljavljajo ošibljene zgradbe najprej v sorazmerno preprostih slovničnih razmerah, okrepljene zgradbe pa najprej v sorazmerno zapletenih slovničnih razmerah. "Najprej“ pomeni: po stanju porajanja zgradbe in pred njeno gramatikalizacijo.

Način utemeljevanja. 1. Izrečena je bila delovna domneva. 2. Na podlagi delovne domneve je bilo izrečenih nekaj iskustveno preverljivih napovedi. 3. Te napovedi so bile preverjene. 4 . Kolikor so bile napovedi uresničene, toliko je bila delovna domneva potrjena.

Delovna domneva. Delovna domneva je sestavljena: 1 . iz domneve, da so zgradbe, obravnavane v naslednjih treh člankih, okrepljene, 2. iz domneve o tem, kaj je $v$ jeziku preprosto in kaj zapletenó, 3. iz domneve, da se okrepljene zgradbe najprej uveljavijo v sorazmerno zapletenih slovničnih razmerah.

Glede tega, kaj je v jeziku preprosto in kaj zapleteno, se članki naslanjajo na dognanja praške šole in "naravnega oblikoslovja" o t.i. zaznamovanosti. V naslednjih parih je prvi člen manj zaznamovan kot drugi: glavni stavek - odvisnik, trdilni stavek - netrdilni stavek, sedanjik - nesedanjik, povedni naklon - ostali nakloni, ednina - neednina, tvorni način - ostali načini, glagol + predmet v tožilniku glagol + predložni ali stavčni predmet, tretja glagolska oseba - netretja oseba.

Postopek pri slovnicni analizi in statistični obdelavi. V vsaki raziskavi sta bila vzpostavljena osnovni in kontrolni vzorec gradiva. Osnovni vzorec vsebuje primerke okrepljene zgradbe, kontrolni pa primerke ustrezne neokrepljene zgradbe ali primerke vseh ostalih zgradb. V statistične namene smo delovno domnevo operacionalizirali takole: “Č je dana verjetnost bolj zaznamovane vrednosti nekega slovničnega parametra $v$ okrepljeni zgradbi in če je dana vérjetnost bolj zaznamovane vrednosti istega slovničnega parametra v ustrezni neokrepljeni zgradbi (ali nasploh zunaj okrepljene zgradbe), potem mora biti prva verjetnost večja od druge in razlika med njima mora biti statistično signifikantna."

Opazke o uspešnosti delovne domneve. Delovna domneva je v člankih A. Snedca in K. Teržan potrjena nekako 75-odstotno, v članku F. Trobevšek-Drobnak nekoliko niže. Doslej spoznani razlogi za delno nepotrjenost delovne domneve: 1 . Delovna domneva velja za funkcijsko idealna besedila. 2. Raziskana besedila so starejša in nudijo zato filološke težave, zaradi katerih je statistična obdelava manj zanesljiva kot sicer. 3. Delovna domneva velja za zgodnje obdobje v razvoju obravnavanih okrepljenih zgradb, možno pa je, da v raziskave niso zajeta popolnoma prava obdobja. 4. Besedila so mogoče preveč heterogena ali prekratka. 5. V nekaterih primerih so se vmešali neskladenjski parametri in "pokvarili" sliko. 6. Teorija o zaznamovanosti ni $v$ vseh svojih delih enako zanesljiva. 